\title{
KONSEP PENDIDIKAN PSIKOLOGI RELIGIUSITAS REMAJA MUSLIM DALAM MOTIVASI BERAGAMA
}

\author{
Andri Nirwana \\ Universitas Serambi Mekkah, Banda Aceh \\ Email: andri.nirwana@serambimekkah.ac.id
}

\begin{abstract}
Abstrak
Pendidikan psikologi beragama remaja dalam Islam mempunyai ketentuan yang telah dikonsepkan untuk mencari keridhaan Allah swt, yaitu dengan pemberian kasih sayang serta mencukupi kebutuhan lahir maupun batin. Pada tingkat pertama, remaja memerlukan kasih sayang yang cukup dalam mengisi jiwa dari kedua orang tua nya. Bentuk kasih sayang berupa emosional, mental selain Materi. Orang tua seharus nya mempunyai waktu khusus bercengkarama dengan anak, berpura pura menjadi teman anak sebagai upaya mendengar curhatan anak. Kondisi kedekatan orang tua dengan anak memberi keuntungan bagi anak untuk menceritakan semua kondisi yang mereka alami, sehingga anak tidak akan mencari pelampiasan lain di luar rumah, terhindar dari Narkoba, sehingga cita cita orang tua terhadap anak dapat terwujud. Konsep pendidikan Psikologi remaja memiliki ketentuan yang lain nya yaitu mengajarkan remaja tentang pendidikan Islam. Pendidikan Islam merupakan kunci keberhasilan orang tua dalam mendidik remaja. Memilih lembaga pendidikan Islam yang menjaga nilai nilai Islam yang sesuai dengan kejiwaan remaja sangat diprioritaskan. Tanpa pendidikan agama, maka mustahil akan mendapatkan anak yang taqwa dan taat pada ibu bapak. Pendidikan agama remaja merupakan prioritas dalam membantuk anak yang baik dan terbebas dari keburukan keburukan sekitar yang tidak bisa diprediksi.
\end{abstract}

Kata kunci: Parenting, remaja

\begin{abstract}
Adolescent religious psychology education in Islam has a concept that has been conceptualized to seek the pleasure of Allah Almighty, namely by giving love and meeting physical and spiritual needs. At the first level, adolescents need enough love to fill the souls of both parents. The form of affection is emotional, mental in addition to Material. Parents should have a special time fighting with children, pretending to be friends with children in an effort to hear the child's curhatan. Conditions of closeness between parents and children benefit children to tell all the conditions they are experiencing, so that children will not look for another outlet outside the home, avoiding drugs, so that the ideals of parents towards children can be realized. The concept of adolescent psychology education has another provision which is to teach adolescents about Islamic education. Islamic education is the key to the success of parents in educating adolescents. Choosing Islamic educational institutions that maintain the values of Islam in accordance with the psychiatric youth is highly prioritized. Without religious education, it is impossible to get a child who is pious
\end{abstract}


and obedient to the father and father. Adolescent religious education is a priority in helping a good child and free from the deterioration of ugliness that can not be predicted around.

Keywords: Parenting, Adolescents

\section{A. PENDAhULUAN}

Kehidupan dalam bermasyarakat memerlukan nilai-nilai yang bisa mengantarkan masyarakat menuju kehidupan yang lebih maju seiring dengan perkembangan zaman tetapi tetap tidak melanggar ketentuan nilai serta ajaran agama yang sudah ditetapkan. Ajaran agama mempunyai peranan penting dalam kehidupan karena ajaran agama itulah yang akan menjadi pedoman untuk melakukan segala aktifitas kehidupan.(AN, 2013) Agama menjadi pedomandalam usaha, dalam bersikap, dalam menghadapi masalah dan juga dalam pergaulan remaja.

Remaja adalah generasi muda yang merupakan calon pewaris negara. Remaja lah yang akan mengisi sejarah dan menentukan kehidupan suatu bangsa, oleh karena itu sering didengar ungkapan bahwa nasib suatu bangsa ditentukan oleh kualitas remajanya. Jika remaja suatu bangsa tidak berkualitas baik dari segi ilmu pengetahuan, keterampilan, pengalaman dan mental serta akhlak yang mulia, maka kehidupan bangsa yang diembannya akan terancam kehancuran.(Nur Utami \& Raharjo, 2019)

Remaja sangat mudah terpengaruh oleh lingkungan. Lingkungan luar pengaruhnya kadang-kadang perlu dihambat dan dicegah, agar tidak terlalu besar perangsangnya terutama bila pengaruh tersebut bersifat negatif. Demikian pula lingkungan dalam diri yang mempengaruhi munculnya perilaku yang tidak dapat ditoleransi oleh masyarakat umum harus dikendalikan dan dicegah kemunculannya. Lingkungan remaja penuh gejolak perasaan, keinginan dan dorongan yang bisa tersalur dalam perilaku.(AN, 2014) Gejolak lingkungan dalam emosionalitas mudah tersalur melalui tingkah lakunya, karena hampir tidak ada patokan yang menghalangi. Landasan dan petunjuk perilaku yang baru harus dibentuk kembali. Perlu skala nilai baru dan sistem norma yang mengarahkan perilaku dan mengendalikan bahkan mencegah keinginan-keinginan yang tidak bisa diterima oleh umum.(Marthoenis, Nirwana, \& Fathiariani, 2019)

\section{B. METODE PENELITIAN}

Penelitian ini menggunakan penelitian kepustakaan (Library Research) berbasis karya tulis baik yang sudah terpublikasi atau pun belum dipublikasi. Teknik Mendapatkan data melalui indeks ensiklopedia, Daftar Pustaka, Latar belakang bisa didapatkan dari buku referensi, majalah ilmiah, katalog dan abstrak.

Studi kepustakaan adalah kegiatan untuk menghimpun informasi yang relevan dengan topik atau masalah yang menjadi obyek penelitian. Informasi tersebut dapat diperoleh dari bukubuku, karya ilmiah, tesis, disertasi, ensiklopedia, internet, dan sumber-sumber lain. Dengan melakukan studi kepustakaan, peneliti dapat memanfaatkan semua informasi dan pemikiranpemikiran yang relevan dengan penelitiannya.(https://www.transiskom.com/2016/03/pengertianstudi-kepustakaan.html) 
Studi kepustakaan adalah tugas yang terus menerus dilakukan selama kegiatan penelitian. Sebuah penelitian akan menghasilkan suatu karya ilmiah, karena itu haruslah mampu memberi sumbangan kepada kemajuan ilmu pengetahuan. Pemeriksaan yang teliti perlu dilakukan, dari mulai memilih judul, agar jangan sampai terjadi duplikasi terhadap masalah yang sudah diteliti oleh orang lain.

Peneliti akan melakukan studi kepustakaan, baik sebelum maupun selama dia melakukan penelitian. Studi kepustakaan memuat uraian sitematis tentang kajian literatur dan hasil penelitian sebelumnya yang ada hubungannya dengan penelitian yang akan dilakukan dan diusahakan menunjukkan kondisi mutakhir dari bidang ilmu tersebut (the state of the art). Studi kepustakaan yang dilakukan sebelum melakukan penelitian bertujuan untuk: Menemukan suatu masalah untuk diteliti, Mencari informasi yang relevan dengan masalah yang akan diteliti, Mengkaji beberapa teori dasar yang relevan dengan masalah yang akan diteliti, Mencari landasan teori yang merupakan pedoman bagi pendekatan pemecahan masalah dan pemikiran untuk perumusan hipotesis yang akan diuji dalam penelitian. Memperdalam pengetahuan peneliti tentang masalah dan bidang yang akan diteliti.Mengkaji hasil-hasil penelitian terdahulu yang ada kaitannya dengan penelitian yang akan dilakukan. Menelaah basil penelitian sebelumnya diarahkan pada sebagian atau seluruh dari unsur-unsur penelitian yaitu: tujuan penelitian, metode, analisis, hasil utama dan kesimpulan. Mendapat informasi tentang aspek-aspek mana dari suatu masalah yang sudah pernah diteliti untuk menghindari agar tidak meneliti hal yang sama selama penelitian berlangsung, studi kepustakaan juga perlu dilakukan, tujuannya adalah: mengumpulkan informasi-informasi yang lebih khusus tentang masalah yang sedang diteliti. Memanfaatkan informasi yang ada kaitannya dengan teori-teori yang relevan dengan penelitian yang sedang dilakukan. Mengumpulkan dan memanfaatkan informasi-informasi yang berkaitan dengan materi dan metodologi dan penelitian tersebut. (https:/www.transiskom.com/2016/03/ pengertian-studi-kepustakaan.html).

\section{HASIL DAN PEMBAHASAN}

\section{Masa Remaja Milenial}

Remaja pada umumnya merujuk kepada golongan manusia yang berumur 12-21 tahun. Dari sudut perkembangan manusia, remaja merujuk kepada satu peringkat perkembangan manusia, yaitu peringkat transisi antara peringkat anak-anak dan peringkat dewasa. Ketika seseorang itu mengalami masa remaja dia akan mengalami berbagai perubahan yang drastis, diantaranya perubahan jasmani, sosial, emosi, dan bahasa. Akibat semua perubahan itu, remaja merupakan orang yang emosinya tidak stabil, dan senantiasa bermasalah.(Nur Utami \& Raharjo, 2019)

Sebenarnya sampai sekarang ini belum ada kata sepakat antara ahli ilmu pengetahuan tentang batas umur bagi remaja. Karena hal itu bergantung kepada keadaan masyarakat dimana remaja hidup dan bergantung pula kepada darimana remaja itu ditinjau. dari segi pandangan masyarakat misalnya, akan terlihat bahwa semakin maju suatu masyarakat, semakin panjang masa remaja itu, karena untuk diterima menjadi anggota masyarakat yang bertanggung jawab diperlukan kepandaian tertentu dan kemtangan sosial, yang meyakinkan. lain halnya dengan masyarakat desa yang masih sederhana, yang hidup dari hasil tani, menangkap ikan dan berburu, masa remaja itu sangat pendek bahkan mungkin tidak ada atau tidak jelas, karena anak dapat 
langsung pindah menjadi dewasa apabila pertumbuhan jasmaninya sudah matang, dia pun langsung dapat dihargai dan sanggup memikul tanggung jawab sosial. Pada masyarakat terbelakang seperti itu, dapat dikatakan bahwa masa remaja tidak ada.(Unayah \& Sabarisman, 2015)

Jika berbicara dari segi Psikologi, maka batas usia remaja lebih bergantung kepada keadaan masyarakat dimana remaja itu hidup. Yang dapat ditentukan dengan pasti yaitu Puber pertama atau mulainya perubahan jasmani dari anak menjadi dewasa kira-kira umur akhir 12 atau permulaan 13 tahun, akan tetapi akhir masa remaja itu tidak sama, di desa berbeda dengan di kota. Setiap anak di desa sudah ikut ke sawah, ladang, laut, untuk mencari rejeki dan setelah pertumbuhan jasmaninya tampak sempurna maka ia diberi tanggung jawab sebagai seorang dewasa dan dia telah dapat menikah, dengan demikian masa remaja bagi anak desa telah berakhir mungkin umurnya baru 16 tahun. Pada masyarakat yang telah maju syarat untuk menjadi seorang yang dewasa adalah mampu diberi tanggung jawab dan memperoleh kematangan dari segala segi, untuk itu perlu perpanjangan umur kira-kira 21 tahun.(Suparmin, 2012) Masalah yang dihadapi oleh para remaja antara lain, Pertumbuhan jasmani cepat, pertumbuhan emosi, pertumbuhan mental dan pertumbuhan pribadi sosial. Ciri - ciri masa remaja berakhir antara lain, pertumbuhan jasmani cepat telah selesai (sudah matang jasmaninya), pertumbuhan kecerdasan hampir selesai, pertumbuhan pribadi belum selesai dan pertumbuhan jiwa sosial masih berjalan (Zakiah Darajat, 2005).

Pubertas dianggap sebagai fase penting dan memiliki fase penting dan memiliki pengaruh yan sangat besar bagi kehidupan setiap individu. Pada masa itulah akan terjadi berbagai perubahan pada organ fisik anak. Perubahan yang paling kentara adalah mengalami masa baligh yang menandai kematangan organ-organ seksual. Masa puber pada anak laki-laki akan ditandai dengan keluarnya Mani ketika dia mimpi indah. Selain itu akan muncul pula ciri-ciri khusus yang menandainya sebagai orang dewasa, yaitu tumbuhhnya rambut kemaluan, kumis, jenggot rambut ketiak, perubahan suara dan kecendrungan untuk berbuat keras. Sementara tanda balih untuk anak perempuan ditandani dengan mengalirnya darah haidh, selain itu akan muncul beberapa ciri khusus yang juga menandainya sebagai orang dewasa, seperti perkembangan pada bagian dada, menonjolnya buah dada, tumbuhnya rambut kemaluan, tumbuhnya rambut ketiak, tulang pinggul dan kedua pantat semakin lebar, kedua paha semakin mengumpal, suaranya berubah dan kecenderungan untuk lembut(Hamid Zafran, 1977).

Ada perbedaan usia baligh pada masing-masing individu anak. Namun periode baligh kebanyakan berkisar antar usia sebelas sampai dengan delapan belas tahun. Kadang-kadang sebagian anak laki-laki mengalami Ihtilam (mimpi indah) pada masa puber awal, yakni sebelum dua belas tahun. Ada pula yang mengalami mimpi indah pada masa puber akhir, yakni sekitar usia delapan belas tahun. Namun ada juga yang mengalami mimpi indah pada masa puber pertengahan yakni sekitar empat belas atau lima belas tahun, Begitu juga dengan sebagian anak perempuan, ada yang mengalami siklus menstruasi pertama pada masa puber pertama. Periode masa puber awal untuk anak perempuan lebih awal dibandingkan dengan masa puber anak lakilaki. Anak perempuan mulai mengalami masa puber pada usia sembilan sampai dengan delapan belas tahun. sdeangkan masa puber pertengahan pada anak perempuan berkisar usia tiga belas tahun(Jamil \& Yusuf, 1983). 
Sebagai kesimpulan para Psikolog telah membagi masa Puber menjadi tiga bagian, sebagai berikut:

a. Masa Puber awal, dimulai dari usia dua belas tahun sampai dengan usia empat belas tahun.

b. Masa puber pertengahan, dimulai dari usia lima belas tahun sampai dengan usia tujuh belas tahun.

c. Masa puber akhir, dimulai dari usia delapan belas tahun sampai dengan usia dua puluh satu tahun.

Rentangan Periode usia baligh yang ditunjukan studi ilmiah mutakhir ternyata sesuai dengan beberapa riwayat hadis Nabi yang memperbincangkan tema ini. Dirwayatkan dari Ibnu Umar, dia berkata:

Aku dihadapkan kepada Rasulullah saw untuk ikut serta dalam pasukan perang. Ketika itu aku masih berusia empat belas tahun, namun Rasulullah saw menolak ku. Pada tahun berikutnya, aku kembali mengajukan diri untuk ikut dalam pasukan perang, ketika itu aku sudah berusia lima belas tahun, maka beliau pun menerimaku(Mujiyo, 2018).

Riwayat hadis di atas telah dijadikan dalil bahwa usia lima belas tahun merupakan usia baligh. Pada usia itulah seorang individu akan bisa membedakan secara tegas sebagai anak kecil atau orang dewasa. Sebagai contoh lain, terjadinya peperangan melawan Bani Quraizhah, karena orang-orang Yahudi melanggar perjanjian mereka dengan Rasulullah saw. Rasulullah saw memblokade mereka selama satu bulan. Baru setelah itu mereka menerima putusan Sa'ad ibn Mu'adz yangmenetapkan bahwa semua orang laki-laki dibunuh dan orang perempuan serta anakanak akan dijadikan tawanan. Mereka tidak mungkin membedakan antara anak kecil dengan orang dewasa dengan cara melihat tanda-tanda masa baligh melalui Ihtilam atau mulai usia. Cara yang mereka gunakan ketika itu adalah dengan memeriksa rambut kemaluan sebagai salahsatu ciri kematangan organ fisik orang baligh. Barang siapa mengalami ihtilam dan telah rumbut kemaluannya, maka dia dibunuh, sedangkan yang belum tumbuh rambut kemaluan nya, maka hanya ditawan. Dirwayatkan dari Athiyah al Quraizi, dia berkata:

Kami telah dihadapkan kepada Nabi SAW pada perang bani Quraizhah. Barang siapa yang telah tumbuh rambut kemaluannya, maka dia dibunuh. Dan barang siapa belum tumbuh rambut kemaluannya, maka dia akan dibiarkan hidup dan aku merupakan salah seorang dari mereka yang dibiarkan hidup(Yasir, 2013).

Bisa ditarik kesimpulan bahwa Rasulullah saw menganggap usia lima belas tahun dan Ihtilam atau keluarnya rambut kemaluan sebagai pertanda usia baligh pada anak-anak dan ternyata tanda-tanda yang dipergunakan oleh Rasulullah saw untuk mengetahui usia baligh ini terus dipergunakan oleh pakar sampai sekarang.

Ketika usia baligh ditandai dengan ihtilam, sehingga perkembangan akal seseorang mulai matang, maka ketika itu juga dia akan mendapatkan beban Syari'at dan harus mempertanggung jawabkan sendiri semua perbuatan yang telah dilakukan. Diriwayatkan oleh Alibahwa Rasulullah saw bersabda:Qalam (malaikat yang mencatat amal perbuatan manusia) tidak difungsikan pada tiga hal: pada orang yang sedang tidur sampai terjaga, pada anak kecil sampai ihtilam dan pada orang gila sampai dia waras(Khan, 1985).

Remaja juga memiliki tujuh kebutuhan utama yaitu; kebutuhan akan kasih sayang, kebutuhan akan keikut sertaan dan diterima di kelompok, kebutuhan mandiri, kebutuhan prestasi, 
kebutuhan akan pengakuan dari orang lain, kebutuhan untuk dihargai dan kebutuhan untuk memperoleh fasilitas hidup(Mukhtar, 2005:70).

\section{Perkembangan Jiwa Beragama pada Remaja Milenial}

Sebelum membahas lebih jauh tentang perkembangan jiwa beragama pada remaja, terlebih dahulu penulis menyebutkan tentang sumber pokok dan paling mendasar tentang timbulnya jiwa beragama pada manusia. Ada dua teori yang telah penulis kumpulkan, yaitu:

a. Teori Monistik

Teori monistik berpendapat bahwa yang menjadi sumber kejiwaan agama adalah satu sumber kejiwaan. Selanjutnya, sumber tunggal manakah yang dimaksud paling dominan sebagai sumber kejiwaan itu? timbul beberapa pendapat yang dikemukakan oleh:

1) Thomas Van Aquino

Sesuai dengan masanya, Thomas Aquino mengemukakan bahwa yang menjadi sumber kejiwaan agama itu ialah berfikir. Manusia bertuhan karena manusia menggunakan kemampuan berfikirnya. Kehidupan beragama merupakan refleksi dari kehidupan berfikir manusia itu sendiri. Pandangan semacam ini tetap mendapat tempatnya hingga sekarang di mana para ahli mendewakan rasio sebagai satu-satunya motif yang menjadi sumber agama. (Jalaludin,2007)

2) Fredrick Hegel

Filosuf Jerman ini berpendapat agama adalah suatu pengetahuan yang sungguh-sungguh benar dan tempat kebenaran abadi. Berdasarkan hal itu agama semata-mata merupakan hal-hal atau persoalan yang berhubungan dengan pikiran. (Jalaludin,2007)

3) Fredrick Schleimacher

Ia berpendapat yang menjadi sumber beragama itu adalah rasa ketergantungan yang mutlak (Sense of depand) dengan adanya rasa ketergantungan yang mutlak ini manusia merasakan dirinya lemah. Kelemahan ini menyebabkan manusia selalu tergantung hidupnya dengan suatu kekuasaaan yang berada di luar dirinya. berdasarkan rasa ketergantungan itulah maka timbul konsep tentang tuhan. (Jalaludin,2007)

4) Rudolf Otta

Menurut dia sumber kejiwaan agama adalah rasa kagum yang berasal dari the Wholly Other (yang sama sekali lain). Jika seseorang dipengaruhi rasa kagum terhadap sesuatu yang dianggapnya lain dari yang lain, maka keadaan mental seperti itu disitilah kan dengan Numinous. Perasaan yang semacan itulah yang menurut pendapatnya sebagai sumber kejiwaan agama manusia. Walaupun faktor-faktor lainnya diakui pula oleh $\mathrm{R}$. Otto namun ia berpendapat Numinous merupakan sumber yang esensial.

5) Sigmund Freud

Pendapat nya ialah unsur kejiwaan yang menjadi sumber kejiwaan agama adalah Naluri seksual.(Nor Nazimi Mohd Mustaffa, Jaffary Awang, \& Aminudin Basir, 2017)

6) Wiliam Mac Dougall

Ia berpendapatbahwa sumber kejiwaan agama adalah marupakan kumpulan dari beberapa instink, maka agama muncul dari dorongan instink secara terintegrasi. Pendapatnya ini banyak dibantah oleh Psikolog lain. 


\section{b. Teori Fakulti}

Teori ini berpendapat bahwa tingkah laku manusia itu tidak bersumber pada satu faktor tunggal, tetapi terdiri dari beberapa unsur, antara lain yang dianggap memegang peranan penting adalah fungsi cipta (reason), rasa (emotion) dan karsa (will). Cipta (reason) berperan untuk menentukan benar atau tidaknya ajaran suatu agama berdasarkan pertimbangan intelek seseorang. Rasa (Emotion) menimbulkan sikap batin yang seimbang dan positif dalam menghayati kebenaran ajaran agama. Karsa (will) menimbulkan amalan-amalan atau doktrin keagamaan yang benar dan logis.(Jalaludin,2007)

Ada beberapa pemuka teori Fakulti diantaranya, G.M Straton mengemukakan Teori Konflik, ia mengatakan bahwa yang menjadi sumber kejiwaan agama adalah adanya konflik dalam kejiwaan manusia. Keadaan yang berlawanan seperti buruk-baik, moral-immoral dan lainlain menimbulkan pertentangan (konflik) dalam diri manusia. Dikotomi (serba dua) termasuk menimbulkan rasa agama dalam diri manusia. Zakiah Darajat berpendapat bahwa pada diri manusia itu terdapat kebutuhan pokok. Beliau mengemukakan selain dari kebutuhan jasmani dan rohani, manusia pun mempunyai suatu kebutuhan akan adanya kebutuhan akan keseimbangan dalam kehidupan jiwanya agar tidak mengalami tekanan. W.H. Thomas mengemukakan bahwa yang menjadi sumber kejiwaan agama adalah empat macam keinginan dasar yang ada dalam jiwa manusia, yaitu: keinginan untuk keselamatan, penghargaan, ditanggapi dan keinginan akan pengetahuan atau pengalaman. (Jalaludin,2007).

Lingkungan memiliki peran penting dalam mewujudkan kepribadian anak. Khususnya lingkungan keluarga.(Marthoenis, Nirwana, \& Fathiariani, 2019) Kedua orang tua adalah pemain peran ini. Peran lingkungan dalam mewujudkan kepribadian seseorang, baik lingkungan pra kelahiran maupun lingkungan pasca kelahiran adalah masalah yang tidak bisa dipungkiri khususnya lingkungan keluarga. Lingkungan keluarga adalah sebuah basis awal kehidupan bagi setiap manusia. Banyak hadis yang meriwayatkan pentingnya pengaruh keluarga dalam pendidikan anak dalam beberapa masalah seperti masalah aqidah, budaya, norma, emosional dan sebaginya. Keluarga menyiapkan sarana pertumbuhan dan pembentukan kepribadian anak sejak dini. Dengan kata lain kepribadian anak tergantung pada pemikiran dan perlakuan kedua orang tua dan lingkungannya. Rasulullah saw bersabda, "Setiap anak yang dilahirkan berdasarkan fitrah, Kedua orang tuanyalah yang akan menjadikannya dia yahudi atau Nasrani atau Majusi.(Shah, 2013)

Perlu ditekankan bahwa lingkungan tidak seratus persen mempengaruhi manusia, karena Allah menciptakan manusia disertai dengan adanya ikhtiar dan hak pilih. Dengan ikhtiarnya, manusia bisa mengubah nasibnya sendiri. Lingkungan adalah sesuatu yang berada di luar batasan-batasan kemampuan dan potensi genetik seseorang dan ia berperan dalam menyiapkan fasilitas-fasilitas atau bahkan menghambat seseorang dari pertumbuhan.

Lingkungan jika dihadapkan dengan genetik ia adalah faktor luar yang berpengaruh dalam pembentukan dan perubahan kepribadian seseorang baik itu faktor-faktor lingkungan pra kelahiran atau pasca kelahiran yang mencakup lingkungan alam, lingkungan ekonomi dan lingkungan sosial. Lingkungan sosial juga mencakup lingkungan keluarga, sekolah, mazhab dan sebaginya. (Jalaludin,2007)

Sehubungan dengan fase perkembangan jiwa agama pada generasi muda, Muzayin Arifin mengemukakan: 
1) Pada usia 6 tahun perhatian anak terhadap agama menjadi semakin kuat, apabila praktek ibadah selalu diberikan kepada mereka, maka sikap tersebut akan semakin kuat. Hubungannya dengan tuhan sangat bersifat pribadi (personal), mereka senang berdo'a dengan sepenuh hati.

2) Pada usia 7 sampai dengan 10 tahun, mereka mulai memperoleh sikap yang matang terhadap agama. Mereka lebih ingin mengetahui tentang tuhan dan banyak mengajukan pertanyaan tentang hal tersebut.

3) Pada usia 10 sampai dengan 12 tahun, anak benar-benar telah dapat menghayati cerita serta peristiwa-peristiwa yang mengandung keghaiban (spritual) seperti kematian dan sebagainya, meskipun belum memahami keghaiban semacam itu dalam hubungannya dengan konsep agama (Arifin: 1980).

Kutipan di atas menggambarkan perkembangan jiwa agama pada anak. Menyangkut perkembangan jiwa agama pada usia Pubertas, Zakiah Darajat mengemukakan: Perkembangan agama pada usia Pubertas sangat ditentukan oleh pendidikan dan pengalaman yang dilalui nya, terutama pada masa pertumbuhan dari umur 0 -10 tahun. Seorang anak yang tidak mendapat pendidikan dan pengalaman agama pada usia ini setelah dewasa akan cenderung kepada sikap negatif terhadap agama. Agama masuk ke dalam pribadi anak bersamaan dengan pertumbuhan pribadinya. Si anak mengenal tuhan melalui orang tua dan lingkungan keluarganya. Kata-kata sikap dan pertumbuhan sangat mempengaruhi perkembangan agama anak. (Zakiah Darajat, 1991)

Kutipan di atas menggambarkan perkembangan agama pada usia pubertas. Agama berkembang pada diri mereka sesuai dengan fase perkembangan pribadinya. Seorang anak mengenal agama melalui lingkungan keluarga, apabila keluarga yang kurang menjalankan ajaran agama akan cenderung mendidik anak untuk tidak taat agama( Fauzi Saleh,2007).

Pada hakikatnya masa remaja yang utama adalah masa menemukan diri, meneliti sikap hidup yang lama dan mencoba-coba yang baru untuk jadi pribadi yang dewasa (Suryabrata,1982). Lebih jauh Elizabet B. Hurlock (1990), menjelaskan bahwa masa remaja merupakan periode peralihan, sebagai usia bermasalah, masa mencari identitas, masa yang tidak realistik serta sebagai ambang masa depan.

Dalam bidang agama, para ahli psikologi agama menganggap bahwa kemantapan beragama biasanya tidak terjadi sebelum usia 24 tahun dari sini, rentangan masa remaja, mungkin diperpanjang hingga 24 tahun (Zakiah Darajat, 1991). Meski terdapat perbedaan dalam rentangan masa remaja, para ahli setuju bahwa masa remaja adalah masa transisi antara masa kanak-kanak yang akan ditinggalkanya menjelang masa dewasa yang penuh tanggung jawab.

Pada dasarnya remaja telah membawa potensi beragama sejak dilahirkan dan itu merupakan fitrahnya. Yang menjadi masalah selanjutnya adalah bagaimana remaja mengembangkan potensi tersebut. Ide-ide agama, dasar-dasar dan pokok-pokok agama pada umumnya diterima seseorang pada masa kecilnya. Apa yang diterima sejak kecilnya akan berkembang dan tumbuh subur, apabila anak (remaja) dalam menganut kepercayaan tersebut tidak mendapat kritikan dan apa yang tumbuh dari kecil itulah yang menjadi keyakinan yang dipeganginya (Zakiah Darajat, 1991).

Sebagaimana tersebut di atas bahwa pengertian tentang ide-ide agama sejalan dengan pertumbuhan kecerdasan. Pangertian hal-hal yang abstrak (yang tidak dapat dirasakan secara 
langsung) seperti pengertian akhirat, surga, neraka dan sebagainya baru dapat diterima anak apabila pertumbuhan dan kecerdasannya telah memungkinkan untuk itu. Menurut Alfred Binet, kemampuan untuk mengerti masalah-masalah yang abstrak secara sempurna perkembangannya sebelum mencapai usia 12 tahun. Kemampuan untuk mengambil kesimpulan yang abstrak dari fakta-fakta yang baru nampak pada usia 14 tahun. Oleh karena itu, anak-anak pada usia 14 tahun telah menolak saran-saran yang tidak dapat dimengerti dan mengkritik pendapat-pendapat tertentu yang berlawanan dengan kesimpulan yang diambilnya.(Zakiah Darajat, 1991).

Perkembangan Kognitif pada usia remaja, menurut Piaget, digambarkan sebagai gerak peralihan cara berfikir yang kongkrit menuju cara berfikir yang proporsional. Dan ini oleh Ronald Goldman telah diterapkan dalam bidang agama. Kesimpulan yang diambil dari penelitian tersebut adalah bahwa pertumbuhan kognitif memberi kemungkinan terjadi perpindahan atau transisi dari agama yang lahiriah menuju agama yang batiniah. Dengan demikian, perkembangan kognitif memberi kemungkinan remaja untuk meninggalkan agama anak-anak yang diperoleh dari lingkungannya dan mulai memikirkan konsep serta bergerak menuju agama "iman" yang sifantnya sungguh-sungguh personal. Hasil penelitian tersebut akan dapat memberi jawab dan menyingkap tabir "mengapa anak usia baligh diberi takhlif atau telah diberi kewajiban untuk melaksanakan kewajiban agama" (Zakiah Darajat, 1991).

Pada tahap selanjutnya, perkembangan intelektual remaja akan mempunyai pengaruh terhadap keyakinan dan kelakuan agama mereka. Fungsi intelektual akan memproses secara analitis terhadap apa yang dimiliki selama ini dan apa yang akan diterimanya. Remaja sudah mulai mengadakan kritik di sana-sini tentang masalah yang ditemui dalam kehidupan masyarakat, mereka mulai mengemukakan ide-ide keagamaan, walaupun hal tersebut kadangkadang tidak berangkat dari suatu perangkat keilmuan yang matang, tetapi sebagai akibat dari keadaan psikis mereka yang sedang bergejolak. Dalam bidang-bidang tertentu yang dianggap cocok dan relevan akan diterimanya, kemudian dengan kemauan keras dijabarkan dalam kenyataan hidupnya, seolah-olah tidak ada alternatif lagi yang harus dipikirkan.

Keadaan emosi remaja yang belum stabil juga akan mempengaruhi keyakinannya pada tuhan dan pada kelakuan keberagamaannya yang mungkin bisa kuat atau bisa lemah, giat atau menurun, bahkan mengalami keraguan, yang ditandai oleh adanya konflik yang terdapat dalam dirinya atau dalam lingkungan masyarakatnya.(Qodriah, 2019).

\section{Perasaan Beragama pada Remaja Milenial}

Menurut Rumke, perasaan ketuhanan baru tumbuh pada usia puber. Namum pendapat ini disanggah oleh Arnold Gessel yang berpendapat bahwa perasaan ketuhanan (beragama) telah mucul sejak usia dini, 0-2 tahun (Faisal,tt: 158-160). Memang perasaan beragama pada remaja dapat dipengaruhi oleh perasaan beragama yang didapat dari masa sebelumnya dan lingkungan dimana ia tinggal. Dan yang lebih penting adalah pengaruh perkembangan psikis dari remaja itu sendiri.

Di dalam surat Al 'Araf Allah berfirman:

"Dan ingatlah ketika tuhanmu mengeluarkan anak-anakAdam dari Sulbi mereka dan Allah mengambil kesaksian terhadap jiwa mereka, (seraya berfirman) Bukan kah aku ini tuhan mu? Mereka menjawab, Betul (engkau tuhan kami) kami menjadi saksi (kami lakukan yang demikian 
itu) agar di hari kiamat kamu tidak akan mengatakan, sesungguhnya kami (bani Adam) adalah orang-orang yang lengah terhadap ini (keesaan Allah)'”S. Al 'Araff (7):172

Melalui ayat tersebut Allah Ta'ala menerangkan bahwa dia telah mengadakan perjanjian dengan anak keturunan Adam. Allah Ta'ala mengambil persaksian mereka atas kemahakuasaannya. Mereka berada di dalam ruh sebelum diciptakan alam dunia ini. Dengan kata lain bahwa ayat ini menerangkan manusia dilahirkan dengan memiliki kesiapan fitrah untuk mengenal Allah swt, beriman dan mentauhidkan-Nya (Najati, 2003).

Gambaran remaja tentang tuhan dengan sifat-sifatnya merupakan bagian dari gambarannya terhadap alam dan lingkungannya serta dipengaruhi oleh perasaan dan sifat dari remaja itu sendiri. Keyakinan agama pada remaja merupakan interaksi antara dia dengan lingkungannya. Misalnya, kepercayaan remaja akan kekuasaan tuhan, menyebabkanya pelimpahan tanggung jawab atas segala persoalan kepada tuhan, termasuk persoalan masyarakat yang tidak menyenangkan, seperti, kekacauan, ketidakadilan, penderitaan, kezaliman, persengketaan, penyelewangan dan sebagainya yang terdapat dalam masyarakat akan menyebabkan mereka kecewa pada Tuhan, bahkan kekecewaan tersebut dapat menyebabkan memungkiri kekuasaan tuhan sama sekali. Jika remaja melihat keindahan alam dengan keharmonisan segala sesuatu, disamping kehidupan keluarga dan lingkungan serasi dan aman tenteram akan tumbuhlah kekagumannya pada tuhan sebagai pencipta alam dengan segala keindahan dan keserasiannya itu. Dengan demikian perasaan keberagamaannya pada tuhan akan bertambah(Zakiah Darajat, 1991).

Perasaan remaja kepada tuhan bukanlah tetap, stabil akan tetapi adalah perasaan yang bergantung pada perubahan-perubahan emosi yang sangat cepat, terutama pada masa remaja pertama. Kebutuhan akan Allah, misalnya, kadang-kadang tidak terasa jiwa mereka dalam keadaan aman, tenteram dan tenang. Sebaliknya Allah sangat dibutuhkan apabila mereka dalam keadaan gelisah, karena menghadapi musibah atau bahaya yang mengancam, ketika ia takut gagal atau mungkin merasa berdosa. Dengan demikian, dapat diambil pengertian bahwa sebenarnya perasaan remaja dalam beragama, khususnya terhadap tuhan tidak lah tetap. Kadangkadang sangat cinta dan percaya kepadanya, tetapi sering pula berubah menjadi acuh tak acuh bahkan menentang dan perasaan ambivalensi inilah ciri khas agama (Zakiah Darajat, 1991).

\section{Motivasi beragama pada remaja Milenial}

Motivasi beragama dapat diartikan sebagai usaha yang ada dalam diri manusia yang mendorongnya untuk berbuat sesuatu tindak keagamaan dengan tujuan tertentu atau usaha yang menyebabkan seseorang beragama(Khoirun Nida, 2019).

Menurut Nico Syukur Dister Ofm, motivasi beragama dibagi menjadi empat motivasi, yaitu:

a. Motivasi yang didorong oleh rasa keinginan untuk mengatasi frustasi yang ada dalam kehidupan, baik frustasi karena kesukaran dalam menyesuaikan diri dengan alam (frustasi alam), frustasi sosial, frustasi moral maupun frustasi kematian.

b. Motivasi beragama karena didorong oleh keinginan untuk menjaga kesusilaan dan tata tertib masyarakat

c. Motivasi beragama karena didorong oleh keinginan untuk memuaskan rasa ingin tahu manusia atau intelek ingin tahu manusia. 
d. Motivasi beragama karena ingin menjadikan agama sebagai sarana untuk mengatasi ketakutan (Dister,1994).

Motivasi yang ditawarkan oleh Nico Syukur Dister itu agaknya sesuai untuk masa remaja, mengingat masa remaja merupakan masa yang labil, belum stabil emosinya. Memang motivasi tersebut merupakan motivasi yang masuk dalam kategori rendah dalam kehidupan manusia, bukan motivasi yang dituntut untuk dimiliki oleh semua agama.

Bila kembali pada masa remaja ada kalanya seseorang remaja bertambah rajin beribadah apabila ia merasa bersalah (berdosa) semakin besar dosanya semakin banyak pula ibadahnya, semakin berkurang rasa bersalah (berdosa), maka ibadahnya pun juga menurun. Maka ibadah bagi remaja seolah-olah hanya untuk menentramkan hati yang gelisah, karena merasa bersalah dan kalah menghadapi dorongan-dorongan yang sedang mengikuti arus darah mudanya dalam pergaulan, sebagaimana diketahui bahwa masa remaja merupakan masa bangkitnya dorongandorongan seksual dalam bentuk yang lebih jelas. Hal ini merupakan bahaya yang mengancam nilai-nilai dan norma-norma yang dipatuhinya selama ini dari sini muncul dalam diri remaja perasaan tidak berdaya menghadapi kekuatan dan dorongan yang sebelumnya belum diketahui. Oleh karena itu, bertambah besarlah kebutuhan akan bantuan luar guna mengatasi dorongandorongan naluri tersebut. Hal ini sesuai dengan firman Allah dalam surat Al Ma'arij ayat 19 - 20 yang artinya: "Sesungguhnya manusia diciptakan bersifat keluh kesah lagi kikir, Apabila ia ditimpa kesusahan ia berkeluh kesah, dan apabila ia mendapat kebaikan ia amat kikir".

Di samping itu, masa remaja juga merupakan masa dimana remaja mulai mengurangi hubungan dengan orang tuanya dan berusaha untuk dapat berdiri sendiri dalam menghadapi segala kenyataan-kenyataan yang ada. semuanya ini menyebabkannya berusaha mencari pertolongan Allah swt. Keyakinan remaja pada masa awal bukanlah berupa keyakinan-keyakinan pikiran, akan tetapi terfokus pada kebutuhan jiwa. Hal ini dapat dilihat dari do'a-do'a remaja yang memohon bantuan kepada Allah supaya terlepas dari gejolak jiwanya sendiri dan tertolong dalam menghadapi naluri-nalurinya karena ia takut akan hukuman batin yang abstrak.(Zakiah Darajat, 1991)

Motivasi beragama pada remaja juga dipengaruhi teman-temannya. Sebagai contoh, bila remaja mengikuti kegiatan dalam kelompok aktifitas keagamaan, maka ia akan ikut terlibat dalam kegiatan tersebut. Namun bila ia bersahabat dengan teman yang tidak mengindahkan agama, ia akan acuh terhadap kegiatan keagamaan. Dengan demikian, dapat diambil pengertian bahwa motivasi dalam diri remaja adalah bermacam-macam dan banyak yang bersifat personal. Adakalanya didorong oleh kebutuhannya akan tuhan sebagai pengendali emosional, adakalanya karena takut atau perasaan bersalah (berdosa), karena di dorong teman-temannya dimana ia berkelompok. Rasulullah saw bersabda: Manusia menurut temannya, maka hendaklah salah seorang memilih siapa yang akan dijadikan temannya. (HR. Abu Daud)

\section{Sikap remaja Milenial dalam beragama}

Berbagai ragam cara dilakukan oleh remaja untuk mengekspresikan jiwa keberagamaanya. hal ini tidak terlepas dari pengalaman-pengalaman yang dilaluinya. Menurut Pemakalah, ekspresi dan pengalaman beragama tersebut dapat dilihat dari sikap keberagamaannya.

Terdapat empat sikap remaja dalam beragama, yaitu: 


\section{a. Percaya ikut-ikutan}

kebanyakan remaja percaya kepada tuhan dan menjalankan ajaran agama karena terdidik dalam lingkungan beragama karena ibu dan bapaknya beragama, teman-teman dan masyarakat sekelilingnya yang beribadah, maka mereka ikut percaya dan melaksanakan ibadah dan ajaranajaran agama sekedar mengikuti suasana lingkungan dimana dimana hidup. Mereka seolah-olah apatis, tidak ada perhatian untuk meningkatkan agama dan tidak mau aktif dalam kegiatankegiatan agama.(Loretha, Nurhalim, \& Utsman, 2017)

Percaya ikut-ikutan ini biasanya dihasilkan oleh didikan agama secara sederhana yang didapat dari keluarga dan lingkungannya. Namun demikian ini biasanya hanya terjadi pada masa remaja awal (usia 13-16 tahun). setelah itu biasanya berkembang kepada cara yang lebih kritis dan sadar sesuai dengan perkembangan psikisnya. Dengan demikian dapat diambil pengertian bahwa ekspresi beragama pada remaja yang percaya ikut-ikutan bersifat apatis. Hal ini dapat dipahami mengingat pengalaman beragama belum dimilikinya. sifat agama yang ingin mendapat perhatian dari orang lain dan lingkungannya merupakan suatu hal yang nantinya mempunyai pengaruh terhadap kepercayaan dirinya dan terhadap orang lain. sebagai remaja yang mendapat perhatian, merasa dirinya mempunyai kelebihan akan menambah kepercayaan terhadap dirinya sendiri, demikian juga remaja tersebut akan menambah kepercayaan pada orang lain.(Rohmiyati, 2018)

Memberi kesibukan atau memberikan tempat yang layak bagi remaja untuk ikut serta dalam kegiatan-kegiatan keagamaan merupakan cara memberikan perhatian yang efektif, karena dengan kegiatan-kegiatan tersebut akan berdaya guna dan berhasil guna, terutama dalam memupuk rasa keagamaan dan kelakuan beragama. Dengan jalan inilah remaja berusaha mengekspresikan jiwa keberagamaannya dalam kegiatan-kegiatan keagamaan sehari-hari. Sebagai contoh, dilibatkannya remaja dalam berbagai kegiatan hari-hari besar Islam, keikut sertaan remaja dalam organisasi pemuda atau organisasi keagamaan dan sebagainya. Pemberian kesibukan tersebut tidak menjadi masalah bagi remaja yang semenjak kecil tumbuh dan berkembang dalam kultur agama serta mendapatkan didikan agama yang baik. Namun, hal ini menjadi persoalan bagi remaja yang semenjak kecil tidak pernah mendapatkan didikan agama. Untuk itu yang terakhir ini terdapat dua kemungkinan yang terjadi, pertama, menambah pengalaman baru bagi mereka, atau kedua justru sebaliknya, menjadi beban remaja karena menjalankannya dengan penuh keterpaksaan. Dalam al Qur'an disebutkan ayat 256 surat $\mathrm{Al}$ baqarah yang artinya tidak ada paksaan dalamberagama. Allah berfirman dalam Al Qur'an surat Al Isra ayat 36: "Dan janganlah kamu mengikuti apa yang kamu tidak mengetahui tentangnya. Sesungguhnya pendengaran, penglihatan dan hati, semuanya akan diminta pertangggungjawabannya" (Al Isra' : 36).

\section{b. Percaya dengan keterpaksaan}

Terjadinya kegelisahan, kecemasan, ketakutan, bercampur aduk dengan rasa bangga dan kesenangan serta bermacam-macam pikiran dan khalayalan sebagai perkembangan psikis dan pertumbuhan fisik, menimbulkan daya tarik bagi remaja untuk memperhatikan dan memikirkan dirinya sendiri. Pada tahap selanjutnya akan mendorong remaja untuk berperan dan mengambil posisi dalam masyarakat. Semangat keagamaan dimulai dengan melihat kembali tentang masalah-masalah keagamaan yang mereka miliki sejak kecil. Mereka ingin menjalankan agama 
sebagai suatu lapangan yang baru untuk membuktikan pribadinya, karena ia tidak mau lagi beragama secara ikut-ikutan saja. Biasanya semangat agama tersebut terjadi pada usia 17 tahun atau 18 tahun (Zakiah Darajat, 1991).

Semangat agama tersebut mempunyai dua bentuk:

1) Dalam bentuk Positif

Semangat agama yang positif, yaitu berusaha melihat agama dengan pandangan kritis, tidak mau lagi menerima hal-hal yang tidak masuk akal. Mereka ingin memurnikan dan membebaskan agama dari bid'ah dan khurafat, dari kekauan dan kekolotan. Mereka juga ingin mengembangkan dan meningkatkan agama sesuai dengan perkembangan pribadinya. pembaruan senantiasa menjadi keinginan mereka, sehingga tidak jarang mereka melancarkan serangan-serangan terhadap adat kebiasaan yang dipandangnya kurang masuk akal dan tidak relevan dengan perkebangan zaman, mereka tidak segan-segan menyerang tokoh pemimpin keagamaan yang selama ini membimbingnya (Zakiah Darajat, 1991)

Semangat yang demikian ada yang sifatnya ekstrovert, yaitu mempunyai kepribadian yang terbuka dengan menunjukan aktifitas agamanya keluar berupa kegiatan-kegiatan sosial, menginginkan perbaikan-perbaikan sosial dan pengabdian yang bersifat agama. Mereka berkecendrungan mengembangkan agama secara terus menerus seseuai dengan pertumbuhannya yang dialaminya. Lain halnya dengan remaja yang bersifat Introvert, yang mempunyai kecendrungan untuk menyendiri dan menyimpan segala perasaan untuk dirinya sendiri, ia akan tenggelam dalam cita-cita, ia merasakan hangat dan lezat berhubungan dengan tuhan lewat do'a-do'a, shalat serta ibadah lainnya tanpa ada aktifitas keluar. Mereka mencari kepuasan dengan mendekatkan diri pada Tuhan dan terdapat kecendrungan kepada dunia Tasawuf.

2) Dalam bentuk Negatif

Semangat keagamaan dalam bentuk kedua ini akan menjadi bentuk kagiatan yang berbentuk Khurafi, yaitu kecendrungan remaja untuk mengambil pengaruh dari luar ke dalam masalah-masalah kegamaan, seperti Bid'ah, khurafat dan kepercayaankepercayaan lainnya. Mereka berusaha mempelajari mantra-mantra, jimat dan sebagainya, untuk dijadikan sebagai penangkal bahaya serta untuk mencapai tujuan yang diinginkan. Bagi remaja yang Introvert, aktivitas tersebut untuk dirinya sendiri. Sementara bagi remaja yan Ekstrovert, selain untuk dirinya sendiri juga ada upaya untuk mengajak orang lain untuk mengerjakannya.

c. Percaya, tapi agak ragu-ragu

Keraguan kepercayaan remaja terhadap agamanya dapat dibagi menjadi dua, yaitu:

1) Keraguan disebabkan kegoncangan jiwa dan terjadinya proses perubahan dalam pribadinya. Hal ini merupakan kewajaran.

2) Keraguan disebabkan adanya kontradiksi atas kenyataan yang dilihatnya dengan apa yang diyakininya atau dengan pengetahuan yang dimilikinya. Pertentangan tersebut antara lain: antara ajaran agama dengan ilmu pengetahuan; antara nilai-nilai moral dengan kelakuan manusia dalam kenyataan hidup; antara nilai-nilai agama dengan 
tindakan para tokoh agama, guru, pimpinan, orang tua dan sebagainya; terjadinya konflik agama pada dirinya(Zakiah Darajat, 1991).

Menurut Zakiah Darajat, kebimbangan tersebut tergantung pada dua faktor penting yaitu: kondisi jiwa yang bersangkutan dan keadaan sosial budaya yang melingkupinya. Mungkin saja kebimbangan dan keingkaran kepada tuhan itu merupakan pantulan dari keadaan masyarakat yang dipenuhi denganpenderitaan, kemerosotan moral, kekacauan dan kebingungan atau mungkin pantulan dari kebebasan berfikir yang menyebabkab orang menjadi sasaran dari arus sekulerisasi.(Zakiah Derajat, 1991)

Keraguan yang dialami oleh remaja memang bukan hal yang berdiri sendiri, akan tetapi mempunyai sangkut paut dengan kondisi psikis mereka, sekaligus juga mempunyai hubungan dengan pengalaman dan proses pendidikan yang dilalui sejak kecil dan kemampuan mental dalam menghadapi kenyataan masa depannya. Bagi beberapa remaja, menurut Elizabeth B Hurlock(2010), keraguan ini membuat mereka kurang taat beragama, sedang remaja lain berusaha untuk mencari kepercayaan lain yang dapat lebih memenuhi kebutuhannya dari pada kepercayaan yang dianut oleh keluarganya. Bila keraguan tersebut dapat diatasi secara positif, maka remaja akan sadar. Namun, jika keraguan tersebut tidak menemukan jalan keluar sesuai dengan ajaran agama, mereka akan cenderung pada ateis (tidak percaya pada tuhan atau agama). Terhadap suatu perkara yang meragukan pikiran Nabi bersabda Tinggalkan apa yang meragukanmu, kerjakanlah apa yang tidak meragukanmu, sesungguhnya kebenaran membawa ketenangan, dan dusta itu menimbulkan keraguan. (At-tirmidzi)

d. Keingkaran terhadap ajaran Agama.

Perkembangan ke arah tidak percaya pada tuhan sebenarnya mempunyai akar atau sumber dari masa kecil. Apabila seorang anak merasa tertekan oleh kekuasaan atau kezaliman orang tua, maka ia telah memendam sesuatu tantangan terhadap kekuasaan orang tua, selanjutnya terhadap kekuasaan apa pun, termasuk kekuasaan tuhan. Di samping itu, keadaan atau peristiwa yang dialami, terutama kebudayaan dan filsafat yang melingkupi, juga ikut mempengaruhi pemikiran remaja. Biasanya apabila remaja telah mengetahui sedikit tentang bermacam-macam ilmu pengetahuan, dirinya menyangka telah hebat dan mendalam ilmunya. Ilmu tersebut kemudian digunakan untuk berdebat dan berdiskusi seolah-olah mereka telah mengetahui dengan sungguh-sungguh apa yang dikatakannya. Filsafat dan pengetahuan baru tersebut dipeganginya, karena dengan itu kepuasaan hatinya akan tercapai. Buku-buku dan pengetahuan tokoh-tokoh dapat menguasai jiwanya, sebagai pengganti kitab suci.(Elisabet, 2010)

Dalam bahasa yang berbeda Elizabeth B. Hurlock menjelaskan bahwa lambat atau cepat remaja membutuhkan keyakinan beragama, meskipun ternyata keyakinan pada masa anak-anak tidak memuaskan. Bila hal ini terjadi, remaja akan mencari kepercayaan baru, kepercayaan pada sahabat karib sesama jenis atau lawan jenis atau pada kultur baru. Kultus baru ini selalu muncul di berbagai negara dan mempunyai daya tarik yang kuat. Bagi remaja yang kurang mempunyai ikatan religius maka akan mudah percaya pada kultus atau kepercayaan batru tersebut. Pada umumnya remaja menjadi sasaran utama.(Elisabet, 2010)

Satu hal lagi yang dapat mendorong remaja sampai mengingkari adanya tuhan adalah karena dorongan seksual yang dirasakanya. Dorongan-dorongan tersebut bila tidak terpenuhi ia 
akan merasa kecewa. Apabila kekecewaan tersebut telah menumpuk akan bertambahlah rasa pesimis dan putus asa dalam hidup. bagi remaja yang kurang mendalam jiwa keberagamaannya, lambat laun akan marah dan benci pada agama, kebiasaan-kebiasaan dan nilai-nilai yang menghalanginya untuk mencapai kepuasan seksual. Memang dorongan seksual itu merupakan nafsu dan nafsu itu selalu menyuruh kepada kejahatan. Firman Allah dalam surat Yusuf, ayat 53: ....Karena sesungguhnya nafsu itu selalu menyuruh kepada kejahatan kecuali nafsu yang diberi Rahmat oleh Tuhan....

Namun demikian, ketidak percayaan mereka, khususnya terhadap tuhan dan keingkaran terhadap ajaran agama bukanlah murni dari pembawaan seseorang, sebab dorongan spritual dalam diri seseorang bersifat fitri. Penulis bukan menyatakan bahwa remaja bisa menjadi Atheis karena kegoncangan yang terjadi pada dirinya akan tetapi cenderung seperti atheis(Hurlock \& Wilson, 2011).

Manusia adalah makhluk yang berfikir (Hayawanun Natiq). Salah satu akibat dari pemikirannya adalah bahwa ia membantu dirinya untuk menentukan keyakinan-keyakinan mana yang harus ditolaknya. Faktor inilah yang agaknya relevan untuk masa remaja, karena disadari bahwa masa remaja mulai kritis dalam menyingkapi soal-soal keagamaan, terutama bagi mereka yang mempunyai keyakinan secara sadar dan bersikap terbuka. Mereka akan mengkritik guru agama mereka yang tidak rasional dalam menjelaskan ajaran-ajaran agama Islam, khususnya bagi remaja yang selalu ingin tahu dengan pertanyaan-pertanyaan kritisnya. Meski demikian, sikap kritis remaja juga tidak menafikan faktor-faktor lainnya, seperti faktor berbagai pengalaman (Sururin, 2004).

Tentang masalah mati. Pada masa remaja telah dapat dipahami bahwa mati itu adalah suatu hal yang tidak dapat dihindari oleh setiap diri, bahkan mati itu adalah phenomena alamiyah yang harus terjadi. Pemikiran remaja tentang mati dalam hal ini adalah terdorong oleh kepentingan emosi yang dirasakannya. Pada masa remaja pengertian tentang mati telah lebih meluas dan mendalam, sehingga ia memandangnya sebagai suatu phenomena umum yang wajar yang akan menimpa semua orang dan juga dirinya sendiri, bahkan akan terjadi atas seluruh makhluk. Yang berarti bahwa pemikirannya itu tidak berhubungan dengan manusia saja, tapi sebagai hukum alam yang umum. Kendati pun pikiran tentang mati itu telah meningkat, namun mereka tidak dapat menghilangkan kegelisahan yang mengambil bentuk seperti takut berpisah dengan keluarga dan takut dirinya akan mati karena berpisah dengan orang yang disayang, banyak dosa akibatnya masuk neraka dan hilangnya cita-cita (Zakiah Darajat, 1991).

Tentang sifat-sifat tuhan, jika remaja menyebutkan sifat tuhan, hal ini tidak timbul dari keyakinannya yang telah tetap, akan tetapi timbul dari emosi dan kedaan jiwanya waktu itu. Maka sifat-sifat yang diberikanya kepada tuhan, kendati pun diambilnya dari didikan agama yang dilaluinya, tetapi diwarnai oleh perasaan dan dorongannya pada waktu tertentu, misalnya Allah adalah penyayang, apabila ia berada dalam situasi yang menghendaki kasih sayangnya dan Allah bersifat membalas kejahatan orang yang aniaya, apabila ia mengharapkan pertolonganNya untuk menghadap lawan yang tak dapat dihadapinya, Allah itu cantik apabila ia sedang terpesona oleh keindahan alam(Zakiah Darajat, 1991). 


\section{KESIMPULAN}

Beberapa pembahasan dan diskusi sebelumnya dapat memberikan beberapa konklusi dalam artikel ini, diantaranya:

1. Jiwa beragama pada remaja tidak ditentukan oleh satu faktor melainkan multi faktor, selain dari fitrahnya, didukung pula oleh didikan orang tua dan lingkungannya tempat dia dibesarkan.

2. Perasaan beragama pada remaja yang mereka serap dari lingkungan menjadi milik pribadinya. Perasaan beragama ini biasanya tidak konstan, kadang-kadang remaja menunjukkan kesalehan yang berlebihan, di saat lain menunjukkan keraguan pada agama yang dianutnya. Di satu sisi remaja membutuhkan rasa keimanan kepada Allah untuk mencari ketenangan diri dari berbagai gejolak jiwa, di sisi lain agama berperan mengekang gejolak biologisnya.

3. Pada dasarnya remaja telah membawa potensi beragama sejak dilahirkan dan itu merupakan fitrahnya. Yang menjadi masalah selanjutnya adalah bagaimana remaja mengembangkan potensi tersebut. Ide-ide agama, dasar-dasar dan pokok-pokok agama pada umumnya diterima seseorang pada masa kecilnya. Apa yang diterima sejak kecilnya akan berkembang dan tumbuh subur, apabila remaja dalam menganut kepercayaan tersebut tidak mendapat kritikan dan apa yang tumbuh dari kecil itulah yang menjadi keyakinan yang dipeganginya.

4. Gambaran remaja tentang tuhan dengan sifat-sifatnya merupakan bagian dari gambarannya terhadap alam dan lingkungannya serta dipengaruhi oleh perasaan dan sifat dari remaja itu sendiri. Motivasi ibadah bagi remaja seolah-olah hanya untuk menentramkan hati yang gelisah bila berbuat salah

5. Orang tua yang hanya berfungsi sebagai panutan dalam pelaksanaan nilai-nilai agama di rumah belum menjamin remaja bisa menjadi anak yang saleh. Fungsi sebagai panutan harus disertai dengan hubungan yang erat antara orangtua dan remaja sehingga remaja dapat menyerap semua nilai-nilai agama langsung dari orangtuanya. Nilai-nilai inilah kelak yang akan menjadi bagian dari jatidirinya.

\section{DAFTAR PUSTAKA}

AN, A. N. (2013). Konsep Islamic State Amien Rais dan Nurcholish Madjid. SUBSTANTIA. 13 (2)

AN, A. N. (2014). أصيول التفسير عند عبد الله بن عمر رضي الله عنهما في تفسير القرآن. Jurnal Ilmiah Peuradeun.

Arifin, Muhammad. (1980). Psikologi dan beberapa aspek kehidupan rohani manusia, Cet II, Jakarta: Bulan Bintang.

Bastaman, Hanna Djumhanna. (1996). Integrasi Psikologi dengan Islam. Jogjakarta: Pustaka Pelajar.

Crapps, Robeth, E., (1994). Perkembangan Kepribadian dan Keagamaan. Jogjakarta: Kanisius.

Darajat, Zakiah. (1985). Membina nilai-nilai moral di Indonesia, Cet 4, Jakarta: Bulan Bintang.

Darajat, Zakiah. (2005). Ilmu Jiwa Agama, Cet 17, Jakarta: Bulan Bintang. 
Elisabet, H. (2010). Psikologi Perkembangan Suatu Pendekatan Sepanjang Rentang Hidup.Jakarta: Erlangga.

Faisal, Sanapiah. dan Mappiare, Andi. (tt). Dimensi-dimensi Psikologi, Surabaya: Usaha Nasional.

Hurlock, J., \& Wilson, M. L. (2011). Searching Twitter: Separating the Tweet from the Chaff. ICWSM.

Jamil, Muhammad.,Yusuf Mansur.Muhammad., dan Fariq 'Abdussalam.(1983).An Numuw Minath Thufulah ilal Muraahaqah, Cet 3, Jeddah: Tihamah.

Khan, M. M. (1985). Sahih Bukhari. Damaskus Sahih Bukhari.

Khoirun Nida, F. L. (2019). MEMBANGUN MOTIVASI BERAGAMA MELALUI PENGUATAN MAKNA HIDUP BAGI PEREMPUAN PEKERJA SEKS KOMERSIAL DI KOMPLEKS LOKALISASI LORONG INDAH KABUPATEN PATI JAWA TENGAH. Nuansa. 19(2).

Loretha, A. F., Nurhalim, K., \& Utsman, U. (2017). Pola Asuh Orangtua dalam Pendidikan Agama pada Remaja Muslim Minoritas di Amphoe Rattaphum Thailand. Journal of Nonformal Education and Community Empowerment. 17 (1).

Marthoenis, M., Nirwana, A., \& Fathiariani, L. (2019). Prevalence and determinants of posttraumatic stress in adolescents following an earthquake. Indian Journal of Psychiatry. 17 (2).

Muchtar, Jauhari.(2005). Fikih Pendidikan, Cet I, Bandung: Remaja Rosdakarya.

Mujiyo, M. (2018). HADIS MUTTAFAQ `ALAIH DALAM KITAB RIYÂDH AL-SHÂLIHÎN. Diroyah: Jurnal Studi Ilmu Hadis. 16 (2).

Najati,Muhammad Utsman. (2003). Al Hadisun Nabawi wal Ilmun Nafs, terj. Wawan Djunaedi Soffandi Psikologi dalam Tinjauan Hadis Nabi, Cet I, Jakarta: Mustaqim.

Nico Syukur Dister Ofm, (1994). Pengalaman dan Motivasi beragama, Jogjakarta: Kanisius.

Nor Nazimi Mohd Mustaffa, Jaffary Awang, \& Aminudin Basir. (2017). Tingkah Laku Beragama Menurut Freud. Akademika. 12 (2).

Nur Utami, A. C., \& Raharjo, S. T. (2019). POLA ASUH ORANG TUA DAN KENAKALAN REMAJA. Focus : Jurnal Pekerjaan Sosial. 12 (1).

Putri, E. L. M., \& Darmawanti, I. (2015). Perbedaan Kepercayaan Diri Remaja Akhir Ditinjau Dari Persepsi Terhadap Pola Asuh Orang Tua. Character: Jurnal Penelitian Psikologi.

Qodriah, L. (2019). KOMPARASI PARENTING SELF-EFFICACY PADA IBU USIA REMAJA DAN DEWASA DI KECAMATAN BANJARHARJO BREBES. Journal of Psychological Science and Profession.

Rohmiyati, Y. (2018). Model Perilaku Pencarian Informasi Generasi Milenial. Anuva.

Saleh, Fauzi. dan Alimuddin. (2007).Pendidikan Islam solusi Problematika (Methode pembinaan anak pada masa pubertas). Banda Aceh: Yayasan Pena.

Shah, M. (2013). Al-Tabarī and the dynamics of tafsīr: Theological dimensions of a legacy. Journal of Qur'anic Studies. 15(1).

Sujanto, Agus. (1998). Psikologi Perkembangan. Jakarta: Angkasa Baru.

Suparmin, M. (2012). MAKNA PSIKOLOGI PERKEMBANGAN PESERTA DIDIK. Ilmiah SPIRIT.

Sururin (2004). Ilmu Jiwa Agama, Cet I, Jakarta: Raja Grafindo Persada. 
Suryabrata, Sumardi. (1982).Perkembangan Individu, Cet I, Jakarta: Rajawali.

Unayah, N., \& Sabarisman, M. (2015). Fenomena Kenakalan Remaja dan Kriminalitas. Sosio Informa. 10 (1).

Yahya Jaya, Motivasi Beragama dalam Agama Islam, makalah disampaikan dalam diskusi ilmiah di IAIN Imam Bonjol Padang tanggal 3 November 1990.

Yasir, M. (2013). Kitab Musnad Ahmad Ibn Hanbal. Kudus: Menara.

Zahran, Hamid.(1977). Ilmu Nafs-Numuw at Thufulah wal Muraahqah, Kairo: 'Alamul kutub. 